\title{
建筑给排水施工的探讨
}

张开

河南君行装饰设计工程有限公司

DOI:10.32629/btr.v2i6.2251

[摘 要] 给排水工程对于现代建筑工程非常重要,并且其与人们生活工作密切相联,因此在建筑给排水施工过程中,为了保障 给排水系统的安全、稳定、节能、高效运行, 本文阐述了建筑给排水施工的主要特点, 对建筑给排水施工存在的主要问题及其 解决策略进行了探讨分析,并论述了建筑给排水施工要点。

[关键词] 建筑给排水施工; 特点; 问题; 解决策略; 要点

\section{1 建筑给排水施工的主要特点分析}

建筑给排水施工的特点主要表现为:

1.1 影响范围广泛

给排水设备对人们正常生活工作具有重要影响, 由于给 排水设备使用范围较广, 给水量和排水量基数较大, 如果造 成停水或排水故障会导致大范围的影响, 因此必须保障给排 水施工质量。

\section{2 消防设计严格}

现代建筑大多为高层或超高层建筑, 其功能、格局等都 较为复杂, 一旦发生火灾, 将很快在建筑内蔓延, 给建筑内人 员疏散以及火灾扑救都带来诸多挑战, 因此安全可靠的消防 给排水系统就需要进行不断优化设置, 以达到消防要求。

\section{3 防震防噪特点}

现代高层建筑对于防震防噪有一定要求, 但是给排水管 道和设备管线有着较长的排设, 其中多种管材种类震源、噪 声源等等繁多, 因此对应管道需要进行防噪声、防沉降及防 震等多种措施, 保证管道处于封闭环境, 避免漏水情况发生, 并且抑制震源和噪声扩散。

\section{2 建筑给排水施工存在的主要问题及其解决策略}

2.1 建筑给排水施工存在的问题分析

2.1.1 管道问题

第一、管道渗漏问题。建筑给排水施工中最常见的便是 管道渗漏问题。造成管道渗漏的原因可以分为三方面来分 析：首先是管材的自身质量问题导致，比如施工中使用的管 材存在砂眼或发生了裂痕等, 很容易导致在使用过程中, 尤 其是在接口位置发生管材渗漏; 其次是管材的选型与建筑环 境不相匹配, 比如对于 PPR 管通过承插热熔方式连接, 而塑 料制品普遍对于温差比较敏感, 受热后容易膨胀, 因此导致 管道发生伸缩变化, 在连接点等位置发生渗漏; 第三个则是 施工工艺问题, 在施工时如果没有按照正确的施工工艺进行, 也很容易导致给水管道出现渗漏问题。第二、管道堵塞问题。 在建筑给排水施工过程中, 经常出现堵管的情况, 分析其原 因是由于在安装管道的过程中工人未按规定采取必要的预 防措施, 使得垃圾等异物进入了管道, 这些异物在水流的冲 击下聚集到管道的弯头处或三通位置处, 造成了管道的堵
塞。管道堵塞将对正常的给排水产生较大的影响, 另外如果 排污管道管径设计较实际需求值小, 也易造成杂物聚集在排 污管道内, 日积月累就会造成管道的堵塞。

2.1 .2 水质、噪音问题

现代高层建筑供水中由于市政水压不够, 普遍采用增压 设备加压二次供水的方式。然而, 部分建筑供水系统施工中 缺少消毒装置的配设, 水箱、管道老化不及时更换, 或长时间 使用不进行清理, 导致水质存在二次污染问题, 威胁住户的 身体健康。而且, 目前给排水管道安装中, 质轻价廉、安装方 便的塑料管材已逐渐取代铸铁管材, 而塑料管道给排水过程 中产生的噪音平均比铸铁管道高 $10 \mathrm{~dB}$, 特别是卫生间排水管 道排水时产生的噪声十分严重, 对居民日常生活影响较大。

\section{2 建筑给排水施工问题的解决策略}

\subsection{1 管道问题的解决策略}

第一、管道渗漏的解决策略。管道渗漏需要考虑两个方 面的因素, 一是施工技术问题, 二是管材质量问题。从施工技 术来看, 施工单位需要注意以下几方面: 首先, 要求能够加强 对施工人员专业技术的培训, 提高施工人员的专业技术能力, 尤其要注意对防止管道渗漏的技术要点的把握, 并且对施工 人员进行合理、严格的分工安排, 保证每一位施工人员的施 工质量。其次要求能够掌握必要的技术措施, 如在进行每层 支管和立管连接、立管与水平干管连接、水平支管与水平干 管连接时必须采取必要的补偿措施。尽量利用折角进行自然 补偿, 如果使用折角进行自然补偿时也无法达到补偿效果, 则要采用其他类型的补偿措施。在进行非直埋管道敷设时, 施工人员必须要考虑到管道遇热膨胀和遇冷收缩的问题, 然 后采取相应的技术措施; 从管材质量控制方面看。首先, 施 工单位需要从采购环节进行管材质量控制, 要选择耐热性和 耐冷性较好的管材, 保证管材的质量。如果在施工中发现管 材有任何问题, 必须要立刻予以替换, 同时要求施工人员在 施工过程中能够加强对管材的保护, 尽量避免对管材产生任 何形式的损害。第二、管道堵塞问题的解决策略。首先, 施 工人员在施工中需要根据当地的实际情况进行具体分析, 如 若当地的实际情况与图纸设计有差别, 则要进行重新设计和 具体施工; 其次, 管径设计要合理, 最好能够设计得更大些, 
以防止因为小块杂物的沉积导致出现管道堵塞的情况; 第三, 镀锌管连接处需要缠绕松紧合适的麻丝, 并且在管道井上方 需要加上木板或者有阻拦大块杂物渗透作用的铁片, 防止管 道堵塞。

2.2 .2 水质、噪音问题解决策略

对于二次加压带来的水质污染问题, 建筑低层可以直接 用市政管网供水或使用小容量水箱供水; 建筑高层在条件允 许的情况下, 可以采用无负压供水技术, 无需水箱, 直接与市 政供水管网连接, 尽量减少由于水滞留带来的二次污染; 而 仍然使用增压设备和它水水箱二次加压供水的建筑, 相关单 位则必须做好清洗和消毒工作。对于给排水系统的噪声问题, 施工中需选用内壁光滑、密度较大的管材, 表面光洁、呈弧 形的陶瓷器具, 管道安装中也要尽量走直线、绕大弯, 以便减 小给排水噪声给居民生活带来的影响。

\section{3 建筑给排水施工要点的分析}

3.1 建筑给排水施工准备要点分析

3.1.1 严格图纸会审

第一、图纸会审是施工准备阶段的重要工作, 也是建筑 工程建设的基本要求, 目的是避免施工图纸出现差错, 作用 是确保工程质量和施工的顺利实施, 降低建设生产成本。因 此在施工前的准备阶段, 需要加强对施工图纸的审核。第二、 应加强土建专业及安装专业的配合, 保证结构工程质量, 满 足对隐蔽安装中技术和质量的要求, 准确预留孔洞的位置及 大小, 避免出现错误的孔洞, 浪费人员材料, 节约施工单位的 资金投入。

\subsection{2 加强材料进场审核}

为保证建筑给排水施工质量, 需要严格把控材料进场关, 针对每批进场材料, 施工单位的相关质检人员必须对进场材 料的品种规格, 外观色泽等进行验收。

\section{2 给水管道施工要点分析}

第一、给水管道安装前应复测地沟, 综合考虑放空和管 道运行的工艺需要, 保证支架符合管道安装的相关数据符合 图纸和有关规范的要求。第二、给水管道施工过程中及完工 后, 应按时做好各种施工技术资料的签证记录, 对埋设的管 道, 应办理隐蔽工程验收, 做好相关工程记录, 相关技术资料 均应整理存档; 第三、穿过建筑结构的管道, 均应加装保护 套管, 管道和套管之间应用阻燃材料填塞。第四、管道安装 工作如有间断, 应及时封闭入承口的深度不敞开的管口。

3.3 预防排水管道堵塞施工要点分析
第一、根据规范要求在乙字管的上部设检查口便于检 修; 第二、排水管道安装时, 应暂不连接埋地排出管与立管, 在立管检查口管插端用托板或其他方法支牢, 并及时补好立 管穿二层的楼板洞, 待确认立管固定可靠后拆除临时支撑 物。在土建装修基本结束后, 对底层及二层以上管道作灌水 试验检查, 证实各管段畅通, 然后将检查口管与底层排出管 连接; 第三、排水管道施工中, 待分段进行排水管道灌水试 验合格后, 在放水过程中如发现排水流速缓慢时, 说明该管 段内有堵塞, 应及时查明管段被堵塞部位, 并将垃圾、杂物等 清理干净; 第四、为了保证楼面地漏及屋面管口免受杂物等 掉入排水管内所有地漏及伸出屋面的透气管、雨水管口应及 时用水泥砂浆封闭, 防止管道堵塞; 第五、排水栓、地漏等 处存水弯塞头在交叉施工中暂不封堵, 待通水试验前冲洗后 再行安装; 第六、给排水工程竣工验收前, 还必须按规范对 室内排水管道作通水能力试验。

3.4 防止管道周边渗漏施工要点分析

建筑给排水工程中的排水管常用的硬聚氯乙烯管, 其特 点是内外壁表面光洁度较高, 穿过楼层的结合部因与混凝土 结合不好, 因而出现管外漏水的现象。应采取如下技术措施: 预先在立管结合部作好记号, 刷上一层塑料粘结剂, 待外表 面形成溶结层时, 滚上中砂, 使其凝固后在塑料管外形成粗 粘表面, 然后再坚管并用细石混凝土吊模; 使用止水环, 将止 水环固定在立管上后打入混凝土中, 增加结合面和泄漏水的 爬行距离, 以达到较好的水密作用。

\section{4 结束语}

综上所述, 给排水工程是现代建筑工程建设的重要内容, 其对人们日常生活具有重要影响, 而且其施工质量对于保障 给排水安全运行非常关键, 因此为了保障建筑给排水系统高 效低能耗运行, 必须加强对其施工进行分析。

\section{[参考文献]}

[1]范章发.建筑给排水设计常见问题及措施研究 [J].建 筑技术开发,2018,45(12):23-24.

[2]曹国军.关于建筑给排水施工中的常见问题及解决措 施分析[J].建材与装饰,2018,(45):32-33.

[3]乔宁.建筑给排水管道安装施工技术 [J].山东工业技 术,2017,(16):135+80.

[4]杨国祥.建筑给排水管道的安装施工技术与质量管控 措施[J].住宅与房地产,2017,(33):193. 